\title{
Why Is English Pronunciation Ignored by EFL Teachers in Their Classes?
}

\author{
Abbas Pourhosein Gilakjani ${ }^{1} \&$ Narjes Banou Sabouri ${ }^{2}$ \\ ${ }^{1}$ Lahijan Branch, Islamic Azad University, Lahijan, Iran \\ ${ }^{2}$ Department of Linguistics, Payame Noor University, Tehran, Iran \\ Correspondence: Abbas Pourhosein Lahijan Branch, Islamic Azad University, Lahijan, Iran. Tel: \\ 98-13-426-32762. E-mail: a_p_g48@yahoo.com
}

Received: July 19, 2016 Accepted: August 17, 2016 Online Published: November 23, 2016

doi:10.5539/ijel.v6n6p195 URL: http://dx.doi.org/10.5539/ijel.v6n6p195

\begin{abstract}
Understandable pronunciation is an important part of communicative competence. Individuals who have acceptable pronunciation can easily improve their language skills better than those who have weak pronunciation. Thus, English pronunciation is very significant for successful communication. Despite the fact that English pronunciation is very important for oral communication and communicative competence, it is sometimes neglected in many language teaching programs. This study examined Iranian teachers' views toward English pronunciation instruction. A quantitative method was used to gather data by an instrument. The researchers used a questionnaire as the instrument of this study. 100 teachers voluntarily participated in this study. Data were collected and analyzed. The findings of this paper indicated that lack of time, motivation, resources, materials, and educational facilities like computer technologies prevented teachers from teaching pronunciation and if teachers want to include pronunciation into their classes, they should be equipped with these factors that can increase their success in teaching English pronunciation.
\end{abstract}

Keywords: English pronunciation, significance, reluctance, EFL teachers

\section{Introduction}

English pronunciation has a great impact on learners' successful communication but it is still ignored by a lot of teachers who pay more attention to teaching grammar and lexis. This is because teachers may feel more uncertain about pronunciation than about grammar and lexis and they are worried that they lack enough knowledge to help their learners effectively. Acquiring acceptable pronunciation is very significant because bad pronunciation habits are not easily corrected. According to Kelly (2002), learners who always mispronounce a series of phonemes create a lot of problems for the speakers of other languages to understand. This can be very disappointing for those who have good grammar and lexis knowledge but have serious problems in understanding and being understood by English speakers.

English pronunciation is still ignored at many EFL classrooms. When teaching pronunciation it is impossible to have a lesson that is only focused on pronunciation practice because pronunciation is unfortunately taken as an additional activity in some university courses. The other problem is that more emphasis is given to individual sounds. Gilbert (2008) stated that there are two main reasons why English pronunciation is ignored in EFL classes. The first reason is that many EFL teachers lack sufficient time in their pronunciation classes and if they have enough time more attention is paid to drills that disappoint both learners and teachers to learn and teach English pronunciation. The second reason deals with psychological factors that have a key role in learning pronunciation because learners are not certain about their English pronunciation as they are about their grammar and lexis knowledge. These psychological obstacles are unconscious and prohibit learners from improving their understandability. In order to overcome these problems, EFL teachers should convince their learners that the aim of pronunciation is not to gain a native accent but to help them pronounce correctly enough to be easily and comfortably understood by other speakers (Ur, 1984).

English pronunciation instruction has been neglected at some universities around the world. For example, some Taiwanese teachers say that English pronunciation is not significant for their learners and just a few tests will require learners to indicate their skills pertinent to English pronunciation (Lin, Fan, \& Chen, 1995). According to 
Wong (1993), many ESL learners and teachers state that it is useless to spend time on pronunciation because it would be very difficult for learners to hear the differences between ship and sheep. Wei and Zhou (2002) said that English pronunciation was neglected in some universities in Thailand. According to Dalton (2002), pronunciation was regarded as "the Cinderella of language teaching" in Mexico and a little emphasis was placed on teaching this important skill.

Unfortunately, English pronunciation does not have a good position in the curriculum design of many universities. This sentence doesn't express that English pronunciation is not so important. The important point here is that the curriculum designers have not paid attention to its significance in English language teaching. On the contrary, pronunciation is an integral part of English language learning. It involves the elements of consonants, vowels, rhythm, and intonation that facilitate the process of communication. This means that English pronunciation is an important part of gaining communicative competence.

If non-native speakers' pronunciation falls below the threshold level while their vocabulary and grammar are satisfactory, they are not able to communicate efficiently (Wong, 1987). When we pay attention to the connection between pronunciation and listening comprehension, the significance of English pronunciation would be more distinct. While listeners expect that spoken English follows certain patterns of rhythm and intonation, speakers should use these patterns to communicate effectively. If the rhythm and intonation are not the same, listeners can't gain the meaning. Listeners should know the organization of speech and the patterns of intonation to interpret speech correctly. It is concluded that pronunciation learning helps learners develop their abilities to understand spoken English. In addition, lack of pronunciation knowledge impacts learners' reading and spelling (Wong, 1993).

Therefore, it can be concluded that English pronunciation is very important and all learners should pay more attention to it as early as possible. Otherwise, learners understand that they can improve all parts of English except their English pronunciation and it would be very difficult for them to eliminate those mistakes which have been repeated for many times. In this paper, the researchers examined Iranian EFL teachers' views toward English pronunciation instruction.

\section{Definition of Pronunciation}

Richard and Schmidt (2002) define pronunciation as the way certain sounds are produced. Pronunciation emphasizes the way sounds are understood by the listeners. They continued that pronunciation is a significant part of English because mispronunciations make it difficult for listeners to understand the meaning of sentences correctly. Harmer (2007) defines pronunciation as the way the sounds of a language are made, the way how and where the word stress and sentence stress are placed, and the way how pitch and intonation are used to indicate our feeling and our meaning.

Pronunciation is defined as the method of producing the sounds for constructing meaning. It consists of consonants and vowels of a language (segments), features of speech such as stress, timing, rhythm, intonation, phrasing (suprasegmental features), and voice quality. All of the mentioned elements can work together when speakers speak so that difficulties in one element may affect another and this may make an individual's pronunciation easy or difficult to understand (Pourhosein Gilakjani, 2012; Yates \& Zielinski, 2009).

\section{Significance of English Pronunciation}

As the importance of language grows, many people understand that just having English grammar and vocabulary knowledge is not enough for successful communication. In today's world, it is not only necessary to comprehend what other speakers utter but it is also important to make one's own speech understandable for the others. While many EFL learners and teachers know the significance of English pronunciation, a lot of EFL learners unfortunately mispronounce sounds, misplace stress in sentences and misuse intonation patterns. Learners whose first language belongs to the syllable-timed languages such as Czech, Italian, Hungarian, where the stress is on all syllables have a lot of problems in adopting the English stress-time patterns. This is an important reason why many adults are struggling with English pronunciation sounds and cannot eliminate the habits of their native pronunciation (Tennant, 2007). This problem can be overcome by exposing EFL learners to as many pronunciation tasks as possible to make them understand the native speakers' pronunciation (Hewings, 1993). When teachers arrange their English lessons, they sometimes ignore to incorporate English pronunciation and they put more emphasis on grammatical structures and lexical syllabus (Kelly, 2007). Anderson et al. (1984) expressed that the duty of teachers for including English spoken language in their EFL classes is as much significant as their duty for paying attention to the written language.

Laroy (1995) declared that English pronunciation cannot be simply instilled in learners' minds. It should be taken 
in their minds to understand it fully. Learners should understand the new sounds as children who hear the language for the first time. Like children who need support for improving their writing skills, EFL learners need guidance in learning the correct pronunciation. Anderson, Brown, Shillcock, and Yule (1984) expressed that some EFL learners have no problems in pronouncing English sounds while other learners should be given special assistance and encouragement. Kelly (2007) said that due to teachers' hesitations in English pronunciation, it is ignored by them in their instruction. Kenworthy (1990) supported the above statement and expressed that EFL teachers should understand that they have a fundamental knowledge of phonetics and a type of sensitivity in giving their learners true instruction and good suggestions in learning English pronunciation. According to Yates and Zielinski (2009), much attention to English pronunciation indicates that pronunciation has a key role in learning English. If teachers don't present the general rules and principles toward comprehensible pronunciation to their EFL learners, nobody will certainly do it. This is the responsibility of EFL teachers to do this by teaching the new sounds, words, sentences, and phrases and arranging appropriate materials for understandable pronunciation in their EFL classes. EFL teachers should explore new ways of indicating, practicing, and giving feedback on English pronunciation that are actually appropriate for learners to learn English pronunciation easily and effectively.

Pourhosein Gilakjani (2012) stated that speakers' English ability can be judged based on their own English pronunciation. If their pronunciation is weak it can have a negative effect on their language ability. Bad pronunciation leads to misunderstanding and can spoil communication. On the contrary, good pronunciation makes listeners judge speakers' language ability easily and effectively even if they have so many grammatical mistakes. Lund (2003) said that good pronunciation helps people understand speakers easily and bad pronunciation confound them and results in misunderstanding even if they have advanced grammar or vocabulary. Pourhosein Gilakjani (2012) demonstrated that English pronunciation is a significant part of English lessons. Pronunciation tasks help learners to be confident of various sounds and sound features and improve their spoken skills. According to Harmer (2005), knowing that where the sounds are in the mouth and which syllables are stressed in words improves learners' comprehension and understandability. Pourhosein Gilakjani (2012) continued that English pronunciation is an important part of communication and pronunciation activities should be incorporated into EFL classes through different materials and tests. Good pronunciation brings about speakers' confidence to communicate and also improves their listening comprehension skill.

Pronunciation instruction is very important for oral communication. It is also a significant part of communicative competence (Hismanoglu, 2006). Although the role of English pronunciation is so significant in English language, a lot of teachers do not pay enough attention to this important skill. The difficulties of pronunciation instruction have been expressed by some researchers. Morley (1991) declared that it is necessary for teachers to teach English pronunciation in ESL and EFL classes, although many teachers do not pay attention to it in their classes. Pourhussein Gilakjani (2012) demonstrated that English pronunciation is one of the least favorite areas for EFL teachers to teach in their classes. Morley (1991) also stated that understandable pronunciation is a necessary part of communicative competence and without having perfect pronunciation skills learners would not be able to communicate effectively. Hismanoglu and Hismanoglu (2011) said that many teachers try to teach grammar, vocabulary, and the four language skills for their learners without incorporating English pronunciation into their curriculum.

\section{Review of Literature on Teachers' Negligence in Teaching English Pronunciation}

There are so many reasons why many teachers do not like to teach English pronunciation in their classes. According to Kelly (2000), there are two main reasons that English pronunciation is neglected by teachers. The first reason is related to the lack of interest in teaching pronunciation. The second reason is pertinent to the teachers' lack of pronunciation knowledge. Many teachers do not know how to teach pronunciation to their learners. Therefore, EFL teachers should improve the necessary skills for teaching pronunciation and indicate considerable enthusiasm for pronunciation instruction. In order to solve these critical difficulties, EFL teachers should know how to pronounce the English sounds, words, and sentences correctly so that they can give good pronunciation skills to their learners. EFL teachers should have strategies of how to attract their learners. Attractive pronunciation materials should be presented by teachers so that learners will not get bored with these materials.

A lot of experienced teachers believe that the lack of pronunciation knowledge can stop them from correct pronunciation instruction and they can eliminate this deficiency through increasing their practical skills in pronunciation instruction while less experienced teachers might be very interested in teaching English pronunciation but due to their concern with grammar and vocabulary they try to first improve grammar and vocabulary and then consider pronunciation (Kelly, 2004). One of the important reasons of pronunciation difficulties is the lack of focus on stress patterns in English language. Teachers give EFL learners less training 
for weak and strong forms of the words and this causes unusual sounds in their pronunciation. Teachers are advised to use appropriate exercises for the weak and strong words for their learners (Bekleyen, 2011). Speakers of English do not have good experiences in listening to foreigners' talks and comprehending their messages. This is not pertinent to the lack of vocabulary knowledge and language structure of nonnative speakers of English but it is exactly related to the strange sounds and incorrect intonation and stress patterns produced by them. Therefore, those who are learning English language have critical difficulties in pronunciation because of not having enough knowledge in the stress and intonation system of the target language (Rivers, 1986).

According to Morley (1991), Celce-Murcia et al. (1996), Jenkins (2004), and Levis (2005), pronunciation instruction is not necessary for nonnative teachers of English because they are not able to teach native like pronunciation. Harmer (2003) believed that teachers who ignore teaching pronunciation have so many things to do and pronunciation just increases a lot of problems for their instruction. Gilbert (2008) said that teachers do not have enough time in their classes to pay attention to pronunciation instruction. He continued that sometimes Iranian teachers have the necessary time for pronunciation instruction, but instruction is accompanied by a series of monotonous and irrelevant subjects. Negative consequences will be brought about by only practicing and repeating sounds and these cause teachers and their students to stop pronunciation instruction and learning. Gilbert (2008) also emphasized that the other reason is related to the suitable teaching materials that are not provided for the Iranian EFL teachers to improve their pronunciation instruction, whereas teachers should be provided with appropriate materials to teach pronunciation well. Boran (2005) said that pronunciation errors can stop communication and EFL teachers should pay particular attention to these errors committed by their learners. When EFL teachers teach vocabulary, they should teach the accurate pronunciation of English words and the phonetic symbols to their learners. This can help them use dictionaries to learn true pronunciation of English words independently when they do not have access to any guidance or models to provide the accurate pronunciation.

Macdonald (2002) carried out a study and interviewed teachers to investigate their views toward English pronunciation. The results of this study indicated teachers' unwillingness to teach pronunciation. It was also revealed that lack of educational resources and insufficient knowledge toward evaluating learners' pronunciation contributed to their reluctance to teach English pronunciation. In another study done by Baker (2011), it was shown that teachers who had a training in pronunciation preferred the instruction of supra-segmental aspects of English pronunciation. Unfortunately, a lot of these teachers did not have enough confidence in the instruction of some features of pronunciation. The ability of Thai-speaking learners to comprehend spoken English when they arrived in the U.S. was examined by Syananondh (1983). The findings showed that there were some reasons for learners not to have good English listening comprehension. They were the various English pronunciation teachers taught to their learners, insufficient vocabulary, and lack of training in English conversation. Baker and Murphy (2011) investigated eight ESL teachers' beliefs about pronunciation and it was indicated that they had negative beliefs in teaching pronunciation to ESL students. Interviews with teachers revealed that they lacked motivation to teach pronunciation. These teachers had little useful knowledge of how to teach pronunciation. Many teachers addressed pronunciation issues only when intelligibility was compromised. Teachers appeared hesitant to take on a monitoring role in students' speech. Finally, several teachers commented that pronunciation was a relatively neglected area with respect to appropriate resources.

There are some studies toward EFL teachers' reluctance to teach English pronunciation in Iran. According to Vafaei (2013), Iranian EFL teachers do not pay enough attention to the pronunciation of words uttered by their learners because they do not know how to pronounce the words appropriately. Behzadi and Fahimniya (2014) said that pronunciation is the most neglected part of English teaching in Iran. For this reason, other skills such as grammar and vocabulary are much better understood by most of the Iranian EFL teachers than pronunciation. According to Abdolmanafi-Rokni (2013), accurate pronunciation is not emphasized in Iranian institutes and universities and students lack enough knowledge about it. He added that many Iranian teachers do not pay enough attention to pronunciation instruction. Hayati (2010) administered a 38-item questionnaire to 230 Iranian English teachers to investigate their views toward teaching pronunciation. The findings indicated concerns regarding the insufficiency of time allocated to pronunciation practice and the problems which exist in the high school textbooks.

Abbasian and Bahmanie (2013) examined the Iranian EFL teachers' views about pronunciation in teaching-learning process. $30 \mathrm{EFL}$ teachers answered a pronunciation knowledge questionnaire. The results indicated that EFL teachers' pronunciation was significantly reflected upon by both EFL teachers and learners. It was also indicated that the Iranian EFL teachers should pay serious attention to their pronunciation while teaching it to their own learners. Nosratinia and Zaker (2014) investigated the phonological transfers and the pronunciation 
errors of Iranian EFL learners. Researchers chose 300 male and female EFL learners for their study. They collected learners' errors involving the definition of the errors and the recognition of those errors. The results of this study showed that there is a positive relationship between the teachers' pronunciation knowledge and that of learners. It was also indicated that pronunciation instruction needs a serious attention by the Iranian EFL teachers.

Despite its significance as a basic constituent of oral communication, pronunciation has been under-researched and neglected among language researchers in Iran (Behzadi \& Fahimniya, 2014). They stated that Iranian researchers have mostly concentrated on skills and sub-skills much more than pronunciation in language teaching. That is why they investigated the influence of two different approaches of teaching pronunciation: intuitive-imitative and analytic-linguistic on students' speaking fluency among a group of Iranian non-native EFL learners. Age was considered as a moderating variable in applying the two approaches. The findings indicated that the intuitive-imitation approach was more fruitful and efficient for the younger participants while the analytic-linguistic approach was more effectual for the older ones.

\section{Objective of the Study}

The objective of this study was to investigate the Iranian EFL university views' toward English pronunciation instruction.

\section{Research Question}

The research question of this study was to:

What are the Iranian EFL university views' toward English pronunciation instruction?

\section{Method}

In this section, the design of the study, population, sampling, research instrument, data collection, and data analysis were completely discussed.

\subsection{Research Design}

A quantitative method was used as the research design of this study. The quantitative method was used to gather data by an instrument. The quantitative instrument consisted of a questionnaire called "Teachers' views toward English pronunciation instruction."

\subsection{Population}

One hundred Iranian EFL teachers at the Islamic Azad Universities of Guilan Province were voluntarily chosen for this study.

\subsection{Sample}

The researchers chose convenience sampling for this study. According to Creswell (2003), in this sampling, participants voluntarily take part in doing the objectives of the study. The participants and the objectives of this study were considered the significant factors in determining sampling for this study. 100 teachers were voluntarily chosen at the Islamic Azad Universities of Guilan Province based on the following criteria:

1) EFL teachers' willingness to participate in the study; (2) being somehow interested in English pronunciation instruction; (3) familiarity with English pronunciation instruction problems; and (4) teaching English pronunciation course for at least six semesters.

\subsection{Research Instrument}

The researchers conducted a survey of 100 Iranian EFL teachers at the Guilan Universities, Iran. A questionnaire consisted of 10 statements was developed with the help of English language teaching experts. Two Iranian experts were requested to validate the validity of questionnaire. The Iranian experts were associate professors at the Faculty of Foreign Languages, University of Tehran, Iran. They were requested to judge the suitability of the items of questionnaire. Softcopies of the items were emailed to the Iranian associate professors after getting their consent to judge the items. Feedback obtained from them was used to make modifications. These modifications were made to provide the comprehensibility and clarity of the items of questionnaire. Questionnaire was developed in English and was not translated into Persian language because the Iranian EFL university teachers had enough comprehension of questionnaire used in this study. The questionnaire put emphasis on teachers' views toward issues that stop them from teaching English pronunciation. The researchers asked teachers to select the best answer in each item.

\subsection{Data Collection}

Data collection procedure for this study was a questionnaire about the Iranian EFL teachers' views toward 
English pronunciation instruction in different issues. Ten questions were designed for this aim. The researchers administered the questionnaire. The items of questionnaires were distributed to the Iranian EFL teachers of English at the Islamic Azad Universities of Guilan Province, Iran. The allotted time for answering the questionnaire was about 13 minutes. Then the researchers gathered the data for the purpose of analysis.

\subsection{Data Analysis}

The collected data was arranged and tabulated. They were analyzed through the use of statistical procedures such as percentages. Suggestions were given based on the findings of this study for improving the Iranian EFL teachers' English pronunciation instruction. Conclusions were drawn according to the objectives of this study.

\section{Findings and Analysis}

Table 8.1 indicates the Iranian EFL teachers' answers to the questionnaire related to their English pronunciation instruction. The questionnaire consisted of 10 items and the Iranian EFL teachers answered all of them. Items were measured on a five-point Likert-type scale ranging from Strongly Disagree (1), Disagree (2), Neutral (3), Agree (4), and Strongly Agree (5). In order to understand better the Iranian teachers' views toward pronunciation instruction, 10 figures have been designed for 10 questions. The researcher has explained all figures separately.

Table 1. Iranian EFL teachers' views toward English pronunciation instruction at the university level

Strongly Agree (SA), Agree (A), Neutral (N), Disagree (D), Strongly Disagree (SD)

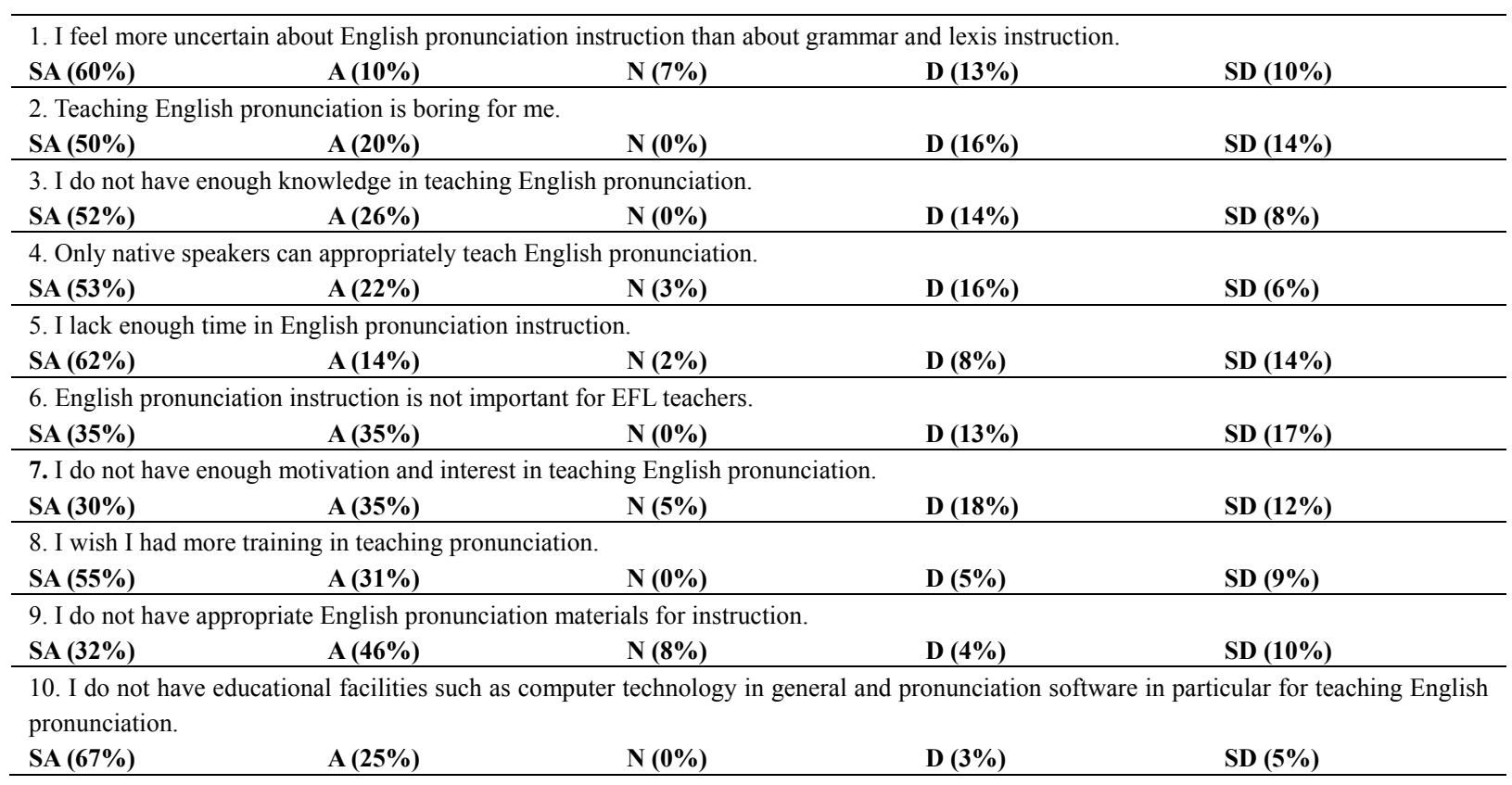

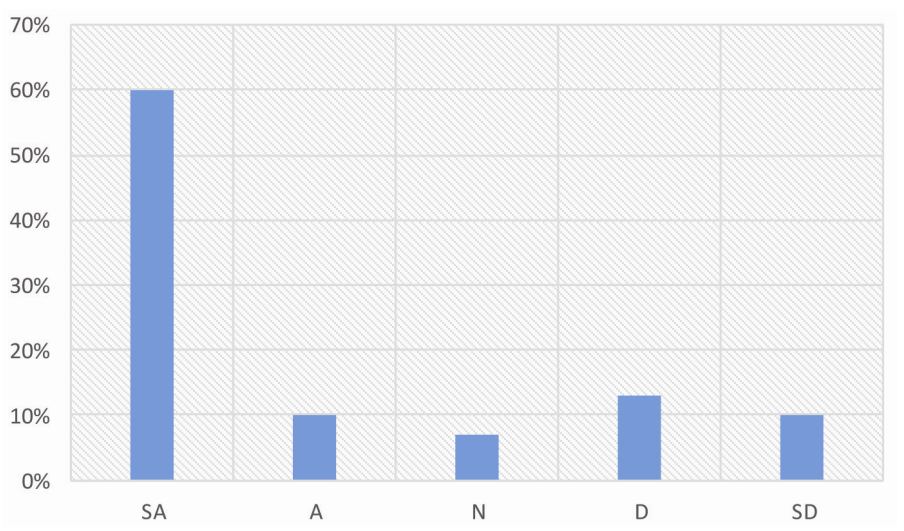

Figure 1. Teachers' response to question 1 
Figure 1 indicates that $60 \%$ teachers are strongly agree, $10 \%$ teachers are agree, $7 \%$ teachers are neutral, $13 \%$ teachers are disagree, and $10 \%$ teachers are strongly disagree to the statement that "I feel more uncertain about English pronunciation instruction than about grammar and lexis instruction." According to the findings obtained from the above Figure, many Iranian EFL teachers strongly agreed that they were not certain about teaching pronunciation as they felt more certain about teaching grammar and lexis.

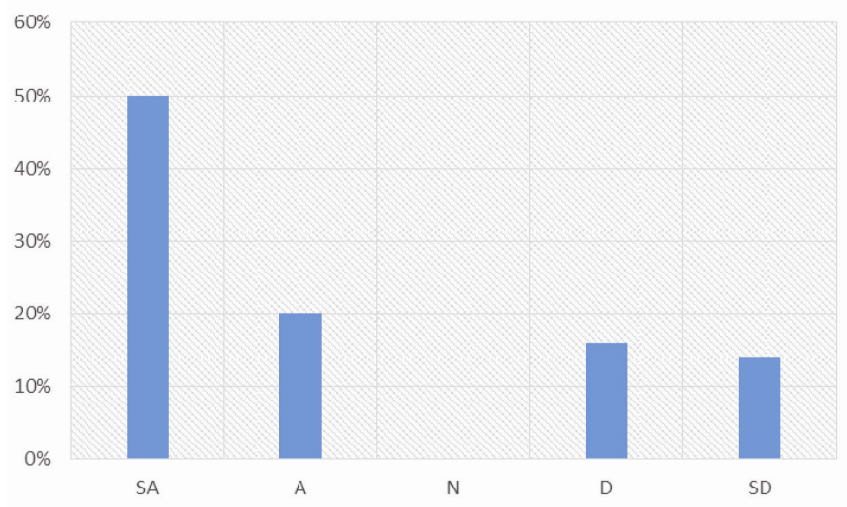

Figure 2. Teachers' response to question 2

According to the findings in Figure 2, 50\% teachers are strongly agree, $20 \%$ teachers are agree, $0 \%$ teachers are neutral, $16 \%$ teachers are disagree and 14\% teachers are strongly disagree to the statement that "Teaching English pronunciation is boring for me." As it can be seen, a large number of teachers agreed that pronunciation instruction was monotonous for them; therefore, they did not like to spend time on teaching pronunciation.

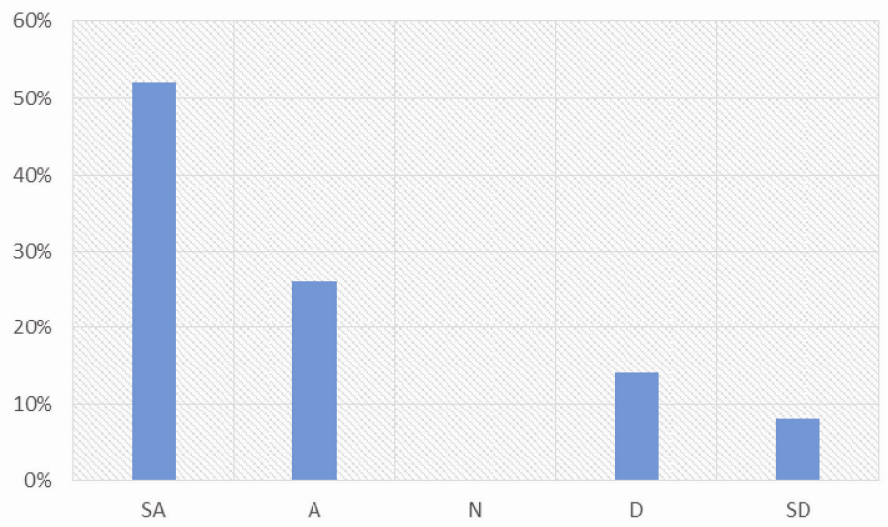

Figure 3. Teachers' response to question 3

As the Figure 3 shows, $52 \%$ teachers are strongly agree, $26 \%$ teachers are agree, $0 \%$ teachers are neutral, $14 \%$ teachers are disagree and $8 \%$ teachers are strongly disagree to the statement "I do not have enough knowledge in teaching English pronunciation." Based on the obtained findings, the majority of teachers lacked sufficient time for teaching pronunciation and so this factor did have negative effect on their instruction. 


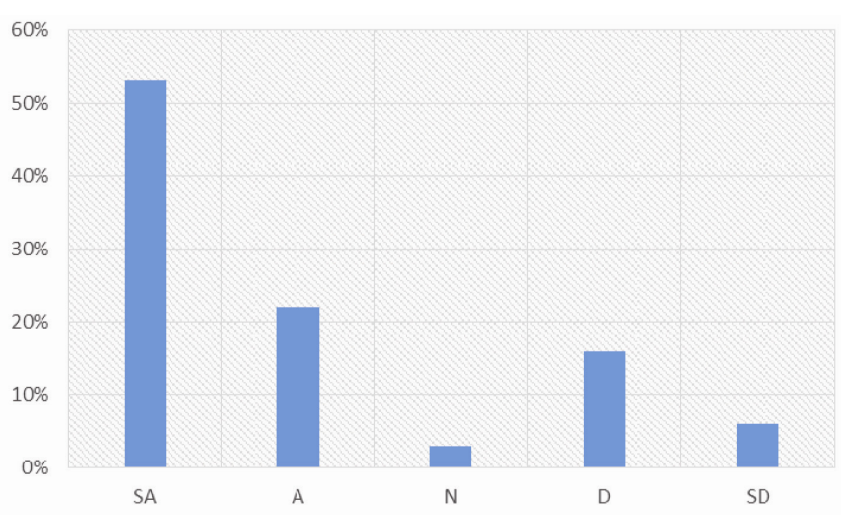

Figure 4. Teachers' response to question 4

Based on the findings of the above Figure, 53\% teachers are strongly agree, $22 \%$ teachers are agree, $3 \%$ teachers are neutral, $16 \%$ teachers are disagree, $6 \%$ teachers are strongly disagree to the statement that "Only native speakers can appropriately teach English pronunciation." A lot of teachers said that just English native speakers are able to teach pronunciation accurately and this is out of their ability to teach pronunciation like native speakers of English.

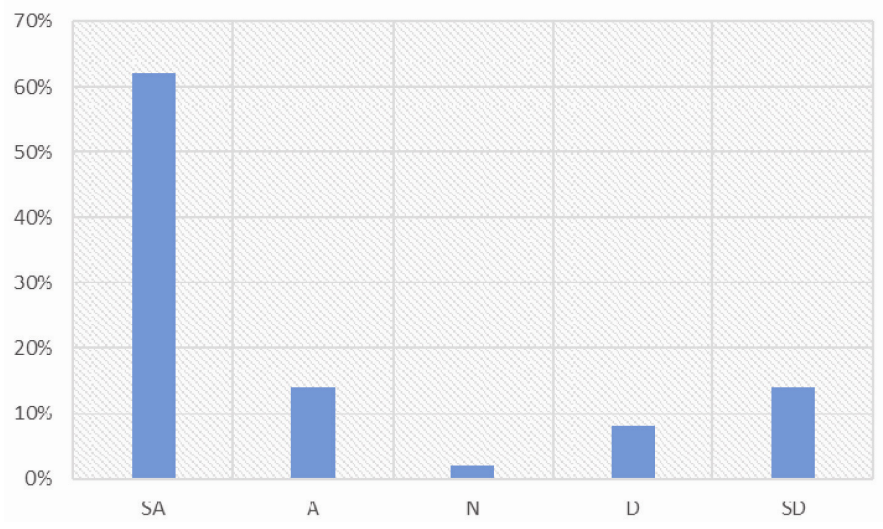

Figure 5. Teachers' response to question 5

As Figure 5 indicates, $62 \%$ teachers are strongly agree, $14 \%$ teachers are agree, $2 \%$ teachers are neutral, $8 \%$ teachers are disagree, and 14\% teachers are strongly disagree to the statement that "I lack enough time in English pronunciation instruction." The majority of teachers stated that they liked to have more time in their instruction but unfortunately they did not have the necessary time to better teach pronunciation.

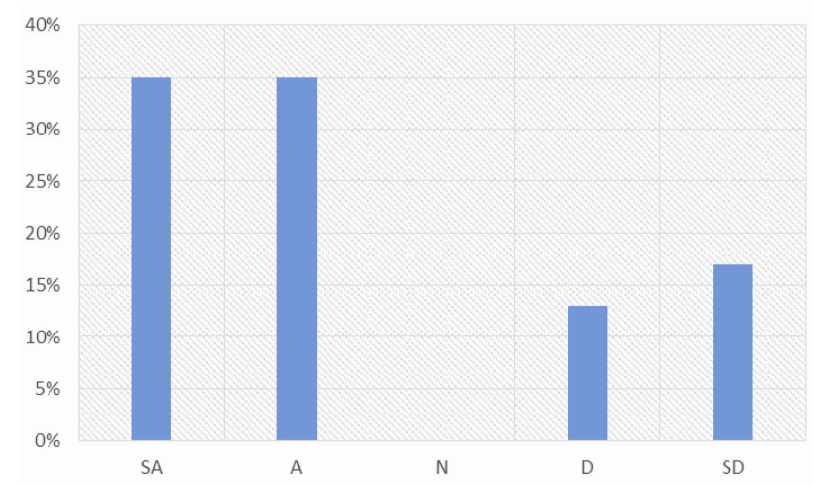

Figure 6. Teachers' response to question 6 
According to Figure 6, 35\% teachers are strongly disagree, 35\% teachers are agree, $0 \%$ teachers are neutral, $13 \%$ teachers are disagree, and $17 \%$ teachers are strongly disagree to the statement that "English pronunciation instruction is not important for EFL teachers." Almost all teachers unanimously stated that pronunciation is not of great importance to their instruction and there is no necessary to pay more attention to it.

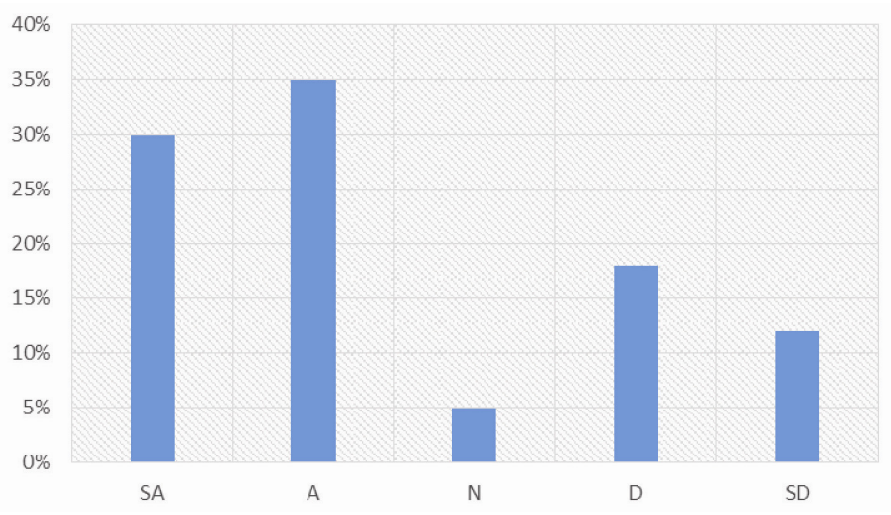

Figure 7. Teachers' response to question 7

According to Figure 7, 30\% teachers are strongly disagree, 35\% teachers are agree, 5\% teachers are neutral, $18 \%$ teachers are disagree, and $12 \%$ teachers are strongly disagree to the statement that "I do not have enough motivation and interest in teaching English pronunciation." The findings showed that the majority of teachers did not have sufficient motivation and were not interested in teaching pronunciation.

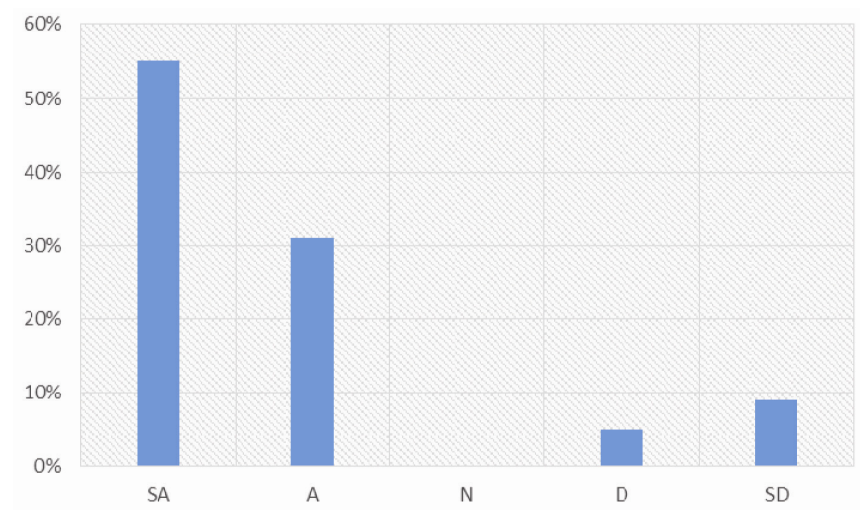

Figure 8 . Teachers' response to question 8

Based on the Figure 8, 55\% teachers are strongly agree, 31\% teachers are agree, $0 \%$ teachers are neutral, 5\% teachers are disagree and $9 \%$ teachers are strongly disagree to the statement that "I wish I had more training in teaching pronunciation." The results indicated that a lot of teachers liked to have more training in their instruction but due to the lack of enough training, they couldn't teach pronunciation effectively. 


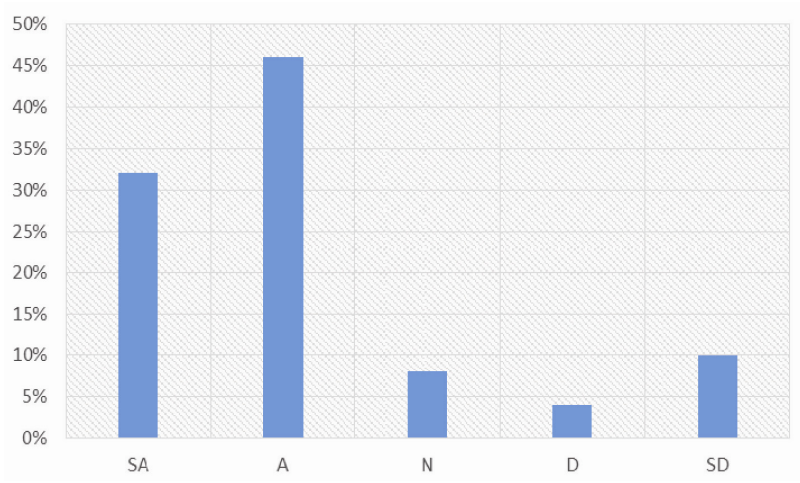

Figure 9. Teachers' response to question 9

According to Figure 9, 32\% teachers are strongly agree, 46\% teachers are agree, $8 \%$ teachers are neutral, $4 \%$ teachers are disagree, and 10\% teachers are strongly disagree to the statement that "I do not have appropriate English pronunciation materials for instruction." According to the findings, a large number of teachers expressed that they did not have access to suitable materials in order to increase the quality of their pronunciation instruction.

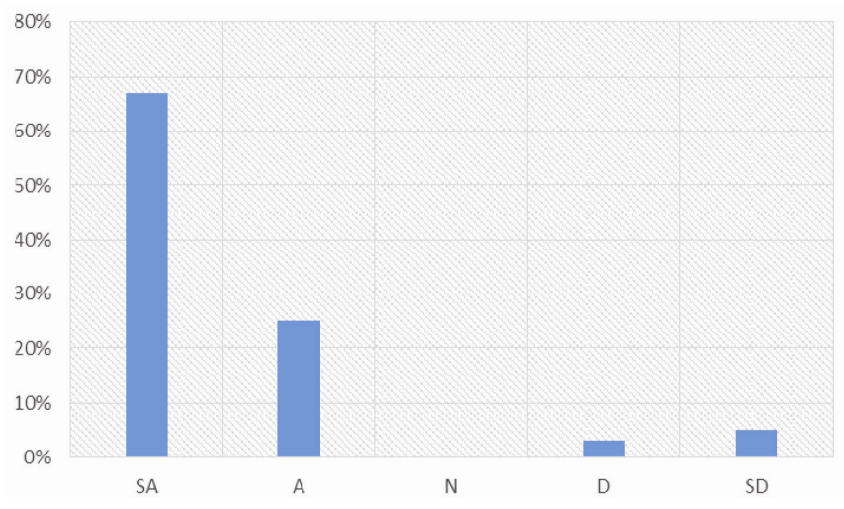

Figure 10. Teachers' response to question 10

As Figure 10 reveals, 67\% teachers are strongly agree, 25\% teachers are agree, $0 \%$ teachers are neutral, 3\% teachers are disagree and 5\% teachers are strongly disagree to the statement that "I do not have educational facilities such as computer technology in general and pronunciation software in particular for teaching English pronunciation." The majority of teachers stated that there were not enough computer technologies at their universities for the effective pronunciation instruction. Therefore, this factor caused them not to teach pronunciation efficiently.

\section{Discussion}

The researchers examined the question "What are the Iranian EFL university views toward English pronunciation instruction? When teachers are not certain about their pronunciation instruction due to many factors such as lack of knowledge they cannot take the most advantage of their instruction. Iranian EFL teachers were not completely certain about teaching pronunciation while they paid more attention to the teaching of grammar and lexis. This finding is in accordance with the finding of Kelly (2002) who said that teachers may feel more uncertain about teaching pronunciation than about grammar and lexis and this is due to their lack of pronunciation proficiency to teach their learners effectively. Based on the results of this study, pronunciation instruction was boring for many Iranian teachers. This certainly had negative effects on teachers' instruction. This finding is according to Kelly's (2000) study, indicating that pronunciation instruction is monotonous for some teachers and teachers should present attractive pronunciation materials for learners not to be bored with their instruction. Moreover, Kelly's (2007) finding is in accordance with the above finding. He said that English pronunciation instruction is ignored by teachers' hesitations because they are not able to teach it appropriately. 
Knowledge of pronunciation is very important for teachers to effectively teach it in their classes. Teachers' knowledge of pronunciation makes them comfortable in front of their learners and decreases their fear, anxiety, and mental pressures. According to the results of this study, most of the Iranian teachers expressed that they lack the necessary knowledge in teaching English pronunciation. The findings of Kenworthy (1990), Morley (1991), Rivers (1986), Kelly (2000), Baker and Murphy (2011), and Abdolmanafi-Rokni (2013) are in line with the above finding. They said that lack of pronunciation knowledge leads to false instruction and teachers should be equipped with the knowledge of phonetics to give their learners true pronunciation instruction. Furthermore, Kelly's (2004) study supports the finding of the present study. He stated that teachers neglect pronunciation instruction in their classes due to the lack of knowledge and this will certainly prevent them from true pronunciation instruction. In addition, Vafaei (2013) supported the above finding. He said that Iranian teachers do not pay attention to their learners' pronunciation because they lack enough knowledge in pronouncing the English words.

This is a reality that English native speakers can teach pronunciation better than non-native speakers of English. This does not mean that non-native speakers should not teach English pronunciation. On the contrary, they should use native speakers' instruction as a good model for their pronunciation instruction. Iranian teachers expressed that only native speakers are able to teach English pronunciation appropriately. Morley (1991), Celce-Murcia et al. (1996), Jenkins (2004), and Levis (2005) had the same opinion. They declared that nonnative teachers of English need English pronunciation instruction because they cannot teach native like pronunciation. Time is a significant factor for the effective teaching of pronunciation. In order to increase the quality of instruction, teachers should have abundant time. Teachers need extra time for preparing teaching materials and resources in their instruction. According to the results of this study, Iranian teachers did not have sufficient time to teach pronunciation. This result is supported by Gilbert's (2008) finding, showing that teachers do not have enough time for pronunciation instruction and sometimes they had enough time for teaching pronunciation but it was followed by a lot of boring and irrelevant subjects. The above finding is also supported by Hayati (2010). He said that teachers did not have sufficient time for pronunciation practice in their classes.

EFL teachers should understand the significance of pronunciation instruction for their learners. When they do not pay attention to the importance of teaching pronunciation their learners will face a lot of problems in the future like understanding native speakers of English. Based on the results of the present study, it was indicated that English pronunciation instruction was not important for EFL teachers. This finding has been supported by Lin, Fan, and Chen (1995), Wei and Zhou (2002), Dalton (2002), Kelly (2007), and Hismanoglu and Hismanoglu (2011) who said that English pronunciation is not so significant for teachers to spend much time on its instruction. Harmer's (2003) finding also supports the finding of this study. He stated that teachers who do not pay attention to teaching pronunciation have a lot of other things to do and pronunciation only increases serious problems for their instruction. Finally, Burgess and Spencer's (2000) study is in line with the finding of this study. He surveyed teachers in the United Kingdom to understand their attitudes toward pronunciation instruction. The findings indicated that although teachers perceived the importance of suprasegmentals, they found them very difficult to teach.

Teachers should have much interest and enough motivation in their pronunciation instruction. Teachers' high motivation arises from their interest to teach pronunciation and their in-depth knowledge of pronunciation. The results of this study indicated that Iranian teachers did not have enough motivation and interest in pronunciation instruction. This has been supported by Kelly (2000) and Baker and Murphy (2011). They said that one of the main reasons that teachers do not like to teach English pronunciation is pertinent to their lack of interest in English pronunciation instruction. When teachers enter the training courses with different technology backgrounds these differences impact the use of computers among them. Teachers who have little use of computer technology for teaching before the training have some difficulties to use them in instruction. More experienced teachers consider the training as an ideal opportunity to update their skills and knowledge and they can use them in more creative and effective ways. Training can expose teachers to a lot of new insights into how computer technology can be used for teaching pronunciation (Sheumaker, Slate, \& Onwuegbuzie, 2001). Iranian teachers liked to have more training in English pronunciation instruction. This finding is very similar to the study of Breitkreutz et al. (2001) who surveyed 67 teachers to understand their attitudes toward teaching English pronunciation. The results indicated that many teachers expressed a desire for training in how to teach pronunciation appropriately.

The findings of the present study showed that Iranian teachers lack suitable materials for teaching English pronunciation. This finding is also supported by the study of Breitkreutz et al. (2001) who said that teachers need more appropriate materials and pronunciation-related curriculum development. MacDonald's (2002) study has the similar result. He carried out interviews with eight teachers that focused on pronunciation teaching views. The results of this study revealed a necessity for better materials and a stronger curriculum to support 
pronunciation instruction. Teachers need educational facilities like computer technologies enable teachers to appropriately teach pronunciation and also help them get the maximum use of these technologies in their instruction. Universities should provide enough financial support such as hardware and software for their teachers to use these technologies for their instruction and support them financially and these factors will enhance their motivation and make teaching more enjoyable for them (Afshari, Abu Bakr, Wong, \& Afshari, 2010; Dashtestani, 2012). The majority of Iranian teachers said that computer technologies are not used for teaching English pronunciation. This finding is supported by Abdolmanafi-Rokni (2013). He expressed that one of the big problems is that computer technology is not used for teaching pronunciation at Iranian universities. They are mostly book-based and universities are teacher-centered and unfortunately computer technology is not used in these learning centers.

\section{Suggestions for Improving English Pronunciation Instruction}

Based on the findings of this paper, the following points are suggested for EFL teachers. EFL teachers should decide when to incorporate English pronunciation instruction into their English lessons. If EFL teachers want to spend the whole lesson to pronunciation instruction, this does not imply that the whole lesson should be arranged only on training English pronunciation. EFL teachers can ask learners to deal with listening activities before working on English pronunciation activities. Moreover, teachers should not just focus on pronunciation of individual sounds, they should rather focus on practicing connected speech, sentence stress, rhythm, and intonation (Harmer, 2005). EFL teachers should include short pronunciation parts into their English lessons and this can be very useful because it can reinvigorate every English lesson. These short pronunciation parts are very beneficial to learners as they will not be worried about long pronunciation activities. EFL teachers should make pronunciation activities a significant part of lesson activities and this can be a very good method of working with English pronunciation. Teachers should include pronunciation activities in all of their listening tasks as learners pay attention to pronunciation features while they are listening to English materials. EFL teachers should point out pronunciation difficulties while they are presenting pronunciation into their EFL classrooms. The ways of pronunciation instruction into the classrooms should not be separately engaged. Many EFL teachers use different methods based on the subjects of a course in their classes (Harmer, 2005).

\section{Conclusion}

In this paper, the researchers investigated some of the important reasons why many teachers are reluctant to teach English pronunciation in their EFL classes. The findings of this study revealed that due to the lack of pronunciation knowledge, lack of institutional resources, insufficiency of suitable pronunciation materials, fear of producing English words incorrectly, lack of training, insufficiency of time, and lack of motivation and confidence, EFL teachers do not like to teach English pronunciation in their classes. EFL teachers should increase their motivation and confidence by means of listening to the different accents of native speakers of English. EFL teachers should increase their pronunciation knowledge through participating in training courses that universities hold for their teachers. Universities, schools, and the other institutional centers should provide sufficient educational resources and appropriate pronunciation materials for their teachers so that they can take the most advantage of these resources in teaching pronunciation. Finally, it can be concluded that enough educational facilities such as computer technology in general and pronunciation software in particular should be provided by all institutional centers for teachers in order to increase their confidence, enhance the quality of pronunciation instruction, eliminate the fear of not being able to pronounce sounds, words, sentences, and phrases correctly, augment their knowledge when teaching pronunciation to their learners, and spend a lot of time to use these technologies so that they can increase their motivation and confidence and be interested in teaching the different features of pronunciation in their classes.

\section{References}

Abbasian, G., \& Bahmanie, A. (2013). EFL Teachers and Learners Reflection on Pronunciation Factor in Teaching-Learning Process and Its Effects on Learners' Motivation. ELT-Voices Journal, 3(2), 62-79.

Abdolmanafi-Rokni, S. J. (2013). The Effect of Listening to Audio Stories on Pronunciation of EFL Learners. MJAL, 5(2), 69-85.

Afshari, M., Abu Bakr, K., Wong, S. L., \& Afshari, M. (2010). Principals' Level of Computer Use and Some Contributing Factors. International Journal of Education and Information Technologies, 2(40), 121-128.

Anderson, A., Brown, G., Shillcock, R., \& Yule, G. (1984). Teaching Talk: Strategies for Production Assessment. Cambridge: Cambridge University Press.

Baker, A. (2011). Discourse Prosody and Teachers' Stated Beliefs and Practices. TESOL Journal, 2(3), 263-292. 
http://dx.doi.org/10.5054/tj.2011.259955

Baker, A., \& Murphy, J. (2011). Knowledge Base of Pronunciation Teaching: Staking out the Territory. TESL Canada Journal, 28(2), 29-50. http://dx.doi.org/10.18806/tesl.v28i2.1071

Behzadi, A., \& Fahimniya, F. (2014). The Effect of Using Two Approaches of Teaching Pronunciation (Intuitive-imitative and Analytic-linguistic) on Speaking Fluency among Iranian EFL Learners. Indian Journal of Fundamental and Applied Life Sciences, 4(1), 27-39.

Bekleyen, N. (2011). Pronunciation Problems of the Turkish EFL Learners. Electronic Journal of Social Sciences, 10(36), 094-107.

Boran, G. (2005). Gazi Eğitim Fakültesi İngilizce ÖğretmenliğiProgramı Öğretmen Adaylarının Genel Olarak Yanlış Telaffuz Ettikleri Kelimeler Üzerine Bir Çalışma. Selçuk Üniversitesi Sosyal Bilimler Enstitüsü Dergisi., 13, 81-90.

Breitkreutz, J., Derwing, T. M., \& Rossiter, M. J. (2001). Pronunciation teaching practices in Canada. TESL Canada Journal, 19(1), 51-61. http://dx.doi.org/10.18806/tesl.v19i1.919

Burgess, J., \& Spencer, S. (2000). Phonology and pronunciation in integrated language teaching and teacher education. System, 28(2), 191-215. http://dx.doi.org/10.1016/S0346-251X(00)00007-5

Celce-Murcia, M., Brinton, D. M., \& Goodwin J. M. (1996). Teaching Pronunciation. A Reference for Teachers of English to Speakers of Other Languages. Cambridge: CUP.

Creswell, J. W. (2003). Research design: Qualitative, quantitative, and mixed methods approaches (2nd ed.). Thousand Oaks, CA: Sage.

Dalton, D. (2002). Some Techniques for Teaching Pronunciation. Retrieved from http://iteslj.org/Techniques/Dalton_Pronunciation.html

Dashtestani, R. (2012). Barriers to the implementation of CALL in EFL courses: Iranian EFL teachers' attitudes and perspectives. JALT CALL Journal, 8(2), 55-70.

Gilbert, J. B. (2008). Teaching Pronunciation Using the Prosody Pyramid. New York: Cambridge University Press.

Harmer, J. (2003). The Practice of English Language Teaching. Oxford: OUP.

Harmer, J. (2005). The Practice of English Language Teaching. Harlow: Pearson Education Limited.

Harmer, J. (2007). The Practice of English Language Teaching (4th ed.). Longman Handbooks for Language Teachers: Pearson Longman.

Hayati, A. M. (2010). Notes on Teaching English Pronunciation to EFL Learners: A Case of Iranian High School Students. Canadian Center of Science and Education, ELT, 3(4), 121-126.

Hewings, M. (1993). Pronunciation Tasks: A Course for Pre-intermediate Learners. Cambridge: Cambridge University Press.

Hismanoglu, M. (2006).Current Perspectives on Pronunciation Learning and Teaching. Journal of Language and Linguistic Studies, 2(1), 101-110.

Hismanoglu, M., \& Hismanoglu, S. (2011). Internet-based Pronunciation Teaching: An Innovative Route toward Rehabilitating Turkish EFL Learners' Articulation Problem. European Journal of Educational Studies, 3(1), 23-36.

Jenkins, J. (2004). Research in Teaching Pronunciation and Intonation. Annual Review of Applied Linguistics, 24(1), 109-125. http://dx.doi.org/10.1017/S0267190504000054

Kelly, G. (2000). How to Teach Pronunciation. London: Pearson Education Limited.

Kelly, G. (2002). How to Teach Pronunciation. Harlow: Longman.

Kelly, G. (2004). How to Teach Pronunciation. England: Longman.

Kelly, G. (2007). How to Teach Pronunciation. Malaysia: Longman.

Kenworthy, J. (1990). Teaching English Pronunciation. Harlow: Longman.

Laroy, C. (1995). Pronunciation. Oxford: Oxford University Press.

Levis, J. M. (2005). Changing Contexts and Shifting Paradigms in Pronunciation Teaching. TESOL Quarterly, 39(3), 369-378. http://dx.doi.org/10.2307/3588485 
Likert, R. (1970). A technique for the measurement of attitudes. In G. Summers (Ed.), (1932). Attitude Measurement. Chicago: Rand McNally.

Lin, H., Fan, C., \& Chen, C. (1995). Teaching Pronunciation in the Learner-Centered Classroom. (ERIC Document Reproduction Service No. ED393292).

Lund, K. (2003). Age and Accent. Retrieved from http://inet.dpb.dpu.dk/infodok/sprogforum/Espr26/Lund-eng.PDF

Macdonald, S. (2002). Pronunciation-Views and Practices of Reluctant Teachers. Prospect, 17(3), 3-18. Retrieved from http://www.nceltr.mq.edu.au/prospect/17/pros17_3smac.asp

Morley, J. (1991). The Pronunciation Component to the Speakers of Other Languages. TESOL Quarterly, 25(3), 481-520. http://dx.doi.org/10.2307/3586981

Nosratinia, M., \& Zaker, A. (2014). An Analysis of Iranian EFL Learners' Pronunciation Errors. International Journal of Language Learning and Applied Linguistics World (IJLLALW), 5(3), 97-108.

Pourhosein Gilakjani, A. (2012). A Study of Factors Affecting EFL Learners' English Pronunciation Learning and the Strategies for Instruction. International Journal of Humanities and Social Science, 2(3), 119-128.

Richards, J. C., \& Schmidt, R. (2002). Longman Dictionary of Language Teaching and Applied Linguistics. Edinburgh Gate: Pearson Education Limited.

Rivers, W. M. (1986). Teaching Foreign Language Skills. Chicago: Chicago University Press.

Sheumaker, F., Slate, J. R., \& Onwuegbuzie, A. J. (2001). The role of In Tech training in the integration of technology into instructional practices among Georgia middle school teachers. Journal of Research on Technology in Education, 33(5), 1-12.

Syananondh, K. (1983). An Investigation of Pronunciation and Learning Strategies: Factors in English Listening Comprehension of Thai-Speaking Graduate Students in the United States. Unpublished doctoral dissertation: The State University of New Jersey - New Brunswick.

Tennant, A. (2007). Sound Foundations: Learning and Teaching Pronunciation; Sound Reasons for Teaching Pronunciation. London: Macmillan Publishers Ltd. Retrieved from http://www.onestopenglish.com/skills/pronunciation/pronunciationmatters/pronunciation-matters-sound-rea sons-for-teachingpronunciation/155507.article/

Ur, P. (1984). A Course in Language Teaching: Practice and Theory. Cambridge: Cambridge University Press.

Vafaei, L. (2013). The Effect of Stress Pattern on Iranian English Language Learners' Pronunciation. International Journal of English Language Education Journal, 1(3), 198-207. http://dx.doi.org/10.5296/ijele.vli3.4011

Wei, Y., \& Zhou, Y. (2002). Insights into English Pronunciation Problems of Thai Students. (ERIC Document Reproduction Service No. ED476746)

Wong, R. (1987). Teaching Pronunciation: Focus on English Rhythm and Intonation. Englewood Cliffs, NJ: Prentice Hall Regents.

Wong, R. (1993). Pronunciation Myths and Facts. English Teaching Forum, 31(4), 45-46.

Yates, L., \& Zielinski, B. (2009). Give It a Go: Teaching Pronunciation to Adults. Sydney, Australia: AMEPRC. Retrieved from http://www.ameprc.mq.edu.au/resources/classroom_resources/give_it_a_go

\section{Copyrights}

Copyright for this article is retained by the author(s), with first publication rights granted to the journal.

This is an open-access article distributed under the terms and conditions of the Creative Commons Attribution license (http://creativecommons.org/licenses/by/4.0/). 